\title{
Biotransformation of lanthanum by Aspergillus niger
}

\author{
Xia Kang ${ }^{1} \cdot$ Laszlo Csetenyi $^{2} \cdot$ Geoffrey Michael Gadd ${ }^{1}$ (D)
}

Received: 13 September 2018 / Revised: 24 October 2018 / Accepted: 27 October 2018 / Published online: 15 November 2018 (C) The Author(s) 2018

\begin{abstract}
Lanthanum is an important rare earth element and has many applications in modern electronics and catalyst manufacturing. However, there exist several obstacles in the recovery and cycling of this element due to a low average grade in exploitable deposits and low recovery rates by energy-intensive extraction procedures. In this work, a novel method to transform and recover La has been proposed using the geoactive properties of Aspergillus niger. La-containing crystals were formed and collected after A. niger was grown on Czapek-Dox agar medium amended with $\mathrm{LaCl}_{3}$. Energy-dispersive $\mathrm{X}$-ray analysis (EDXA) showed the crystals contained $\mathrm{C}, \mathrm{O}$, and $\mathrm{La}$; scanning electron microscopy revealed that the crystals were of a tabular structure with terraced surfaces. X-ray diffraction identified the mineral phase of the sample as $\mathrm{La}_{2}\left(\mathrm{C}_{2} \mathrm{O}_{4}\right)_{3} \cdot 10 \mathrm{H}_{2} \mathrm{O}$. Thermogravimetric analysis transformed the oxalate crystals into $\mathrm{La}_{2} \mathrm{O}_{3}$ with the kinetics of thermal decomposition corresponding well with theoretical calculations. Geochemical modelling further confirmed that the crystals were lanthanum decahydrate and identified optimal conditions for their precipitation. To quantify crystal production, biomass-free fungal culture supernatants were used to precipitate La. The results showed that the precipitated lanthanum decahydrate achieved optimal yields when the concentration of La was above $15 \mathrm{mM}$ and that $100 \%$ La was removed from the system at $5 \mathrm{mM} \mathrm{La}$. Our findings provide a new aspect in the biotransformation and biorecovery of rare earth elements from solution using biomass-free fungal culture systems.
\end{abstract}

Keywords Rare earth elements $\cdot$ Lanthanum $\cdot$ Aspergillus niger $\cdot$ Biotransformation $\cdot$ Biorecovery

\section{Introduction}

Rare earth elements (REE) are vital to the world's fastest growing markets including renewable energy, electric vehicles, telecommunication and defence technologies and the demand for them has risen year on year (Goodenough et al. 2018). Lanthanum is moderately abundant in the Earth's crust and represents a group of REE that include 14 lanthanides that have multiple industrial applications such as additives in the production of high-performance alloys and as catalysts in glass and ceramics manufacturing and in the refinement of crude oil (Kilbourn 1987; Tyler 2004; Massari and Ruberti 2013). Lanthanum oxide $\left(\mathrm{La}_{2} \mathrm{O}_{3}\right)$ is an important material in microelectronics as it exhibits the best electrical properties in metal oxide semiconductor field effect transistors and could

Geoffrey Michael Gadd

g.m.gadd@dundee.ac.uk

1 Geomicrobiology Group, School of Life Sciences, University of Dundee, Dundee, Scotland DD1 5EH, UK

2 Concrete Technology Group, Department of Civil Engineering, University of Dundee, Dundee, Scotland DD1 4HN, UK be the ideal substitute for $\mathrm{SiO}_{2}$ in $\mathrm{CMOS}$ integrated circuits (Leskelä and Ritala 2003; Kakushima et al. 2007). Another potential application in environmental technology is that it can be used as a highly efficient absorbent for the removal of phosphorus from polluted water (Zhang et al. 2011; Xie et al. 2015). REE primarily occur in associated minerals that are scattered among other mineral-containing ores, meaning that mining can be costly and ineffective due to a lack of economically exploitable deposits worldwide, with the average grade of REE-containing ores being usually less than 10\% (Humphries 2010). Traditional physico-chemical methods involve multiple steps of leaching with a combination of hazardous chemicals, e.g. nitric acid and butyl phosphonate, with a huge amount of energy consumption only achieving a recovery rate of approximately $1 \%$ (Preston et al. 1996). This is very low when compared with other industrially important elements such as platinum group metals (PGMs) where average recovery rates can amount to 96\% or even higher (Patel and Dawson 2015). Therefore, new approaches for the recovery of REE from mines, leachates and waste materials need to be proposed, which could, if adopted for commercial use, greatly alleviate the shortage of supplies of these metals. 
Through the mechanism of biologically induced mineralization (BIM) (Gadd 2010), whereby organisms create favourable conditions for extracellular chemical precipitation of mineral phases by modifying their extracellular microenvironment, metal-containing compounds can be formed. Aspergillus niger is a common soil fungus and an important industrial microorganism for the production of citric acid (Currie 1917; Kubicek and Rohr 1985; Mattey 1992; Papagianni 2007). It is also noted for producing various other organic acids including gluconic and oxalic acids, and all these can have a huge role in geomicrobial transformations of minerals and metal speciation (Gadd 1999; Gadd et al. 2014). The application of oxalic acid is an effective means by which certain metals can be precipitated in the form of insoluble metal oxalates of general formula $\mathrm{M}_{x}\left(\mathrm{C}_{2} \mathrm{O}_{4}\right)_{y}$. $\mathrm{zH}_{2} \mathrm{O}$. Bioprecipitation of metals mediated by oxalic acidproducing fungi, such as $A$. niger, can provide a potentially useful mechanism for metal biorecovery from solution (Ilyas et al. 2017; Liang and Gadd 2017). The recovery of elements is an indispensable step in the bioleaching process for both REE-bearing ores and waste materials (Ilyas et al. 2017). Some approaches to recovering REE from La-containing ores and electronic wastes by involving microbial participation have also been reported, e.g. bioleaching, bioaccumulation and biosorption (Ismail et al. 2015; Ayora et al. 2016; Park et al. 2016). Some previous studies have shown that REE can be mobilized from solid materials such as spent catalysts and luminescent powder from cathode ray tubes by sulphuroxidizing bacteria, such as Acidithiobacillus ferrooxidans, A. thiooxidans and Leptospirillum ferrooxidans (Barmettler et al. 2016). In a separate study, 50\% of the total REE was released from spent fluid catalytic cracking catalyst by 4-dayold cell-free supernatant of Gluconobacter oxydans, indicating that organic acid-producing microorganisms can effectively induce bioleaching and improve the recovery of REE from waste materials (Reed et al. 2016). Hopfe et al. (2017) discovered that significant amounts of REE were leached from lanthanide-containing fluorescent phosphor material using both a biomass-free supernatant and living culture of a mixture of yeasts and acetic acid bacteria. Some preliminary research has reported the dissolution of commercial lanthanide oxides (Schwartz and Näveke 1980), by different strains of A. niger, which confirmed the accessibility of lanthanides to Aspergillus species. Supernatants of cultures of $A$. niger, A. ficuum and $A$. terreus have been used by some researchers to study bioleaching of REE from natural sources, such as carbonaceous shales, monazite sand, red mud and Th-U concentrate (Hassanien et al. 2013; Amin et al. 2014; Qu et al. 2015; Brisson et al. 2016; Desouky et al. 2016; Keekan and Jalondhara 2017). REE in ores can be recovered as oxides through several steps including acid leaching, filtration, precipitation using oxalic acid and calcination, and this has been in practice as a part of the recovery process for some minerals such as bastnasite and monazite (Sinha et al. 2016). Despite fungi exhibiting a significant role in biogeochemical cycles for metals and metalloids (Gadd 2007), few studies have clarified interactions of fungal species with REE. Therefore, more information on the mechanisms and conditions effecting the biotransformation of REE is clearly needed. The present study examines the bioprecipitation of lanthanum oxalate by A. niger and adds new knowledge about the microbial biotransformation of lanthanides.

\section{Materials and methods}

\section{Microorganism and media}

The fungal strain used in this study was Aspergillus niger (ATCC 1015), which was routinely maintained in Petri dishes containing commercial malt extract agar (MEA) (Lab M Limited, Bury, Lancashire, UK) at $25{ }^{\circ} \mathrm{C}$ in the dark. Modified Czapek-Dox medium (MCD) contained the following substances $\left(1^{-1}\right.$ Milli-Q $\left.\mathrm{H}_{2} \mathrm{O}\right)$ : glucose $30 \mathrm{~g}, \mathrm{NaNO}_{3} 3 \mathrm{~g}$, $\mathrm{Na}_{2} \mathrm{HPO}_{4} 1 \mathrm{~g}, \mathrm{MgSO}_{4} \cdot 7 \mathrm{H}_{2} \mathrm{O} 0.5 \mathrm{~g}, \mathrm{KCl} 0.5 \mathrm{~g}$ and $\mathrm{FeSO}_{4}$. $7 \mathrm{H}_{2} \mathrm{O} 0.01 \mathrm{~g}$. Where required, $15 \mathrm{~g}$ of agar no. 1 (Lab M, Bury, UK) was added to make solid agar medium. The final $\mathrm{pH}$ of MCD medium was adjusted to $\mathrm{pH} 5.5$ using $1 \mathrm{M} \mathrm{HCl} /$ $\mathrm{NaOH}$ prior to autoclaving for $15 \mathrm{~min}$ at $115{ }^{\circ} \mathrm{C}$. To achieve higher oxalate precipitation yields, nitrate $\left(\mathrm{NO}_{3}{ }^{-}\right)$was used as the nitrogen source in modified AP1 medium, composed of the following $\left(\mathrm{l}^{-1}\right.$ Milli-Q $\left.\mathrm{H}_{2} \mathrm{O}\right): \mathrm{NaNO}_{3} 3 \mathrm{~g}, \mathrm{KH}_{2} \mathrm{PO}_{4} 0.5 \mathrm{~g}$, $\mathrm{MgSO}_{4} \cdot 7 \mathrm{H}_{2} \mathrm{O} 0.2 \mathrm{~g}, \mathrm{CaCl}_{2} \cdot 6 \mathrm{H}_{2} \mathrm{O} 0.05 \mathrm{~g}, \mathrm{NaCl} 0.1 \mathrm{~g}, \mathrm{FeCl}_{3}$. $6 \mathrm{H}_{2} \mathrm{O} 0.0025 \mathrm{~g}$, trace metals $\left(\mathrm{ZnSO}_{4} \cdot 7 \mathrm{H}_{2} \mathrm{O} 0.004 \mathrm{~g}, \mathrm{MnSO}_{4}\right.$. $4 \mathrm{H}_{2} \mathrm{O} 0.004 \mathrm{~g}$ and $\mathrm{CuSO}_{4} \cdot 5 \mathrm{H}_{2} \mathrm{O} 0.0004 \mathrm{~g}$ ) and glucose $20 \mathrm{~g}$. The medium was adjusted to $\mathrm{pH} 5.5$ using $1 \mathrm{M} \mathrm{HCl} / \mathrm{NaOH}$ prior to sterilization at $115{ }^{\circ} \mathrm{C}$ for $15 \mathrm{~min}$. For preparation of solid plates, $15 \mathrm{~g}$ of agar no. 1 was applied to $1000 \mathrm{ml}$ of medium.

\section{Lanthanum biotransformation}

Lanthanum chloride heptahydrate (99.9\%) (Sigma-Aldrich, St Louis, MO, USA) was used as the La source in experiments using solid agar plates. A $500-\mathrm{mM} \mathrm{LaCl}_{3}$ stock solution was prepared and sterilized through a Minisart Syringe Filter (pore size $0.2 \mu \mathrm{m}$ ) (Sartorius Lab Instruments $\mathrm{GmbH} \& \mathrm{Co}$, Goettingen, Germany) before use. Each Petri dish contained 25-ml La-spiked medium, which was prepared by pipetting appropriate amounts of the La stock solution into the nutrient agar when cooled to $55^{\circ} \mathrm{C}$ after autoclaving at $115^{\circ} \mathrm{C}$. The surface $\mathrm{pH}$ of the plates was measured using a flat-tipped $\mathrm{pH}$ probe (VWR International, Lutterworth, England, UK). A 90mm-diameter cellophane membrane (Focus Packaging and Design Ltd., Louth, UK), which was treated by washing with Milli-Q water and autoclaving at least three times in Milli-Q 
water at $121^{\circ} \mathrm{C}$ for $15 \mathrm{~min}$, was placed on top of the agar surface to separate the fungal biomass from the medium. Plugs ( $6 \mathrm{~mm}$ diameter) were cut from the leading edge of a vigorously growing $A$. niger colony using a sterile cork borer and transferred to La-containing plates and incubated in the dark at $25{ }^{\circ} \mathrm{C}$ until the colony reached the edge of the plate. Colony diameter was measured daily in two directions across the colony. To recover the biomass, the fungal colony growing on the membrane was removed from the surface, washed three times with Milli-Q water and oven-dried at $105{ }^{\circ} \mathrm{C}$ until constant weight. Biomass yield was determined by measuring the dry weight; the surface $\mathrm{pH}$ after fungal growth was measured as described previously. A tolerance index (TI) was calculated according to the following formula: $\mathrm{TI}=$ (dry weight of Laexposed biomass/dry weight of control biomass $\times 100 \%$ ) (Sayer et al. 1995; Wei et al. 2013). Growth was presented as colony expansion rates, growth rates being defined as millimetres per day, calculated according to a linear regression equation. Each treatment was conducted at least in triplicate.

Crystals that were formed in the agar were recovered by gently homogenizing the agar in $50 \mathrm{ml}$ Milli-Q water at $80^{\circ} \mathrm{C}$ in a crystallizing dish (Sayer and Gadd 1997; Li et al. 2015). After sedimentation and washing at least three times with cool Milli-Q water, the extracted crystals were stored in a desiccator until constant weight, and accurately measured using an HR-150A analytical balance (A\&D Instruments Ltd., Abingdon, Oxfordshire, UK).

For lanthanum biotransformation experiments in liquid medium, A. niger was inoculated on MEA slants and grown for a few days until profuse growth resulted. To obtain a spore suspension, $20 \mathrm{ml}$ of sterile $0.1 \%\left(v / v_{\text {aq }}\right)$ Tween 80 was added to the slants and mixed well by vortexing. The resulting suspension was then filtered through sterile muslin cloth to remove mycelia from the suspension. The spores were washed three times using sterile Milli-Q water to remove remaining Tween 80 by centrifugation at $2553 \times g$ for $30 \mathrm{~min}$. Serial dilution was carried out to obtain a spore concentration of $1 \times$ $10^{8} \mathrm{ml}^{-1} ; 1 \mathrm{ml}$ of this inoculum was transferred to $99 \mathrm{ml}$ liquid medium in a 250-ml Erlenmeyer flask, which was maintained in a shaking incubator (Infors Multitron Standard, Rittergasse, Switzerland) at $125 \mathrm{rpm}$ in the dark at $25{ }^{\circ} \mathrm{C}$ for 7 days. For harvesting, the culture was aseptically filtered through sterile 63- $\mu$ m nylon mesh (John Staniar \& Co. Ltd., Manchester, UK) to obtain a biomass-free supernatant which was stored at $4{ }^{\circ} \mathrm{C}$ prior to experiments. Supernatant $\mathrm{pH}$ was measured as described previously.

La biotransformations by fungal supernatants were performed in $15 \mathrm{ml}$ centrifuge tubes, incubated on a roller mixer (Stuart Equipment, Stone, Staffordshire, UK) at room temperature for $24 \mathrm{~h}$, prepared by adding $1 \mathrm{ml}$ sterile $\mathrm{LaCl}_{3}$ of the desired concentration into $9 \mathrm{ml}$ fungal supernatant to achieve a final volume of $10 \mathrm{ml}$ and La concentrations of $0,1,3,5,7,11$, $15,20,30,40$ and $50 \mathrm{mM}$. After precipitation, minerals produced were collected by sedimentation and removal of the supernatant and then washed three times with Milli-Q water before being dried in a desiccator at room temperature until constant weight, in order to calculate crystal yield. Each treatment was performed at least in triplicate.

\section{Crystal yield and La assay}

To accurately estimate precipitation yield and removal of $\mathrm{La}$ from the supernatant after precipitation, dried crystal samples were accurately weighed as previously described. After fungal supernatant reactions with $\mathrm{LaCl}_{3}$, resulting supernatants were collected by centrifugation $(2553 \times \mathrm{g}, 30 \mathrm{~min})$ prior to measurement of lanthanum concentrations using the Arsenazo III colorimetric method (White and Gadd 1990; Rohwer et al. 1995; Ivanov and Ermakova 2001) and an Ultrospec 2100 pro spectrophotometer (Biochrom Ltd., Holliston, MA, USA) at an optical density of $658 \mathrm{~nm}$. This was achieved by pipetting 1-ml sample into a test tube with $1 \mathrm{ml} 0.02 \%(w / v)$ Arsenazo III (Sigma-Aldrich, St. Louis, USA) in pH 2.8 potassium hydrogen phthalate buffer with a final volume of $10 \mathrm{ml}$ made up by adding Milli-Q water. The concentration of lanthanum in the solution was calculated based on a calibration curve created using a series of standard solutions at 0 , $1.44,3.60,7.20,10.80$ and $14.40 \mu \mathrm{mol}^{-1} \mathrm{La}$. The La removal rate was defined as $\mathrm{R}_{\mathrm{La}}=\left(m_{1}-m_{2}\right) \times 100 \%$, where $m_{1}$ is the amount of La added to the reaction system and $m_{2}$ that of the remaining $\mathrm{La}$ in the supernatant after reaction.

\section{Geochemical modelling}

Geochemical modelling was carried out to analyse interactions of lanthanum with oxalate and $\mathrm{pH}$ in the aqueous state using Geochemist's Workbench (GWB) edition 12.0 (Aqueous Solutions LLC, Urbana-Champaign, USA), which is mainly comprised of two subprograms, i.e. SpecE8 for calculating species activities and Act2 for creating stability diagrams (Ceci et al. 2015a, b; Li and Gadd 2017). The stability diagrams of both $\left(\mathrm{C}_{2} \mathrm{O}_{4}\right)_{2}{ }^{-}$and $\mathrm{La}^{3+}$ activities as a function of $\mathrm{pH}$ were constructed using Act2 to simulate changes in the mineral species under ideal conditions; all ion activities were calculated using SpecE8 according to their concentrations in the liquid medium. As A. niger was found to secrete $\sim 25 \mathrm{mM}$ oxalic acid after 12-day growth in a previous study (Ceci et al. 2015b), the activity of oxalate was calculated based on $25 \mathrm{mM}$ $\left(\mathrm{C}_{2} \mathrm{O}_{4}\right)_{2}{ }^{-}$in the equilibrium system, while that of lanthanum was set at $1 \mathrm{mM} \mathrm{La}^{3+}$, which was found to be an effective concentration to precipitate $\mathrm{La}$ as oxalate. Activities for other chemicals in simulated spent AP1 medium were calculated using the following concentrations: $35.3 \mathrm{mM} \mathrm{NaNO}_{3}$, $3.7 \mathrm{mM} \mathrm{KH}_{2} \mathrm{PO}_{4}, 1.7 \mathrm{mM} \mathrm{NaCl}, 0.8 \mathrm{mM} \mathrm{MgSO}{ }_{4} \cdot 7 \mathrm{H}_{2} \mathrm{O}$, $0.2 \mathrm{mM} \mathrm{CaCl} 2 \cdot 6 \mathrm{H}_{2} \mathrm{O}, 17.9 \mu \mathrm{M} \mathrm{MnSO}{ }_{4} \cdot 4 \mathrm{H}_{2} \mathrm{O}, 13.9 \mu \mathrm{M}$ $\mathrm{ZnSO}_{4} \cdot 7 \mathrm{H}_{2} \mathrm{O}, 9.3 \mu \mathrm{M} \mathrm{FeCl}{ }_{3} \cdot 6 \mathrm{H}_{2} \mathrm{O}$ and $1.6 \mu \mathrm{M} \mathrm{CuSO}_{4}$. 
$5 \mathrm{H}_{2} \mathrm{O}$. For MCD fungal supernatant, the concentrations used were the following: $35.3 \mathrm{mM} \mathrm{NaNO}_{3}, 7.0 \mathrm{mM} \mathrm{Na}_{2} \mathrm{HPO}_{4}$, $6.7 \mathrm{mM} \mathrm{KCl}, 2.0 \mathrm{mM} \mathrm{MgSO}{ }_{4} \cdot 7 \mathrm{H}_{2} \mathrm{O}$ and $36.0 \mu \mathrm{M} \mathrm{FeSO}_{4}$. $7 \mathrm{H}_{2} \mathrm{O}$. All simulated equilibrium conditions were set at $25{ }^{\circ} \mathrm{C}$ under 1.013 bars atmospheric pressure.

\section{EDXA and SEM}

Dried La-containing crystals were mounted on adhesive carbon tape stuck to aluminium electron microscopy specimen stubs (JEOL, $25 \mathrm{~mm} \times 8 \mathrm{~mm}$ ) for determination of elemental composition using an energy-dispersive X-ray spectroscopy system (Oxford Instruments Inca, Abingdon, Oxfordshire, UK) embedded within a JEOL JSM 7400F field emission scanning electron microscope (JEOL Ltd., Tokyo, Japan) operating at an accelerating voltage of $15 \mathrm{kV}$ for $100 \mathrm{~s}$. Samples on the stub were plated with a layer of 10-nm gold and platinum using a Cressington 208HR sputter coater (Cressington Scientific Instruments Ltd., Watford, England, UK) prior to examination using the emission scanning electron microscope (JEOL JSM7400F) running at an accelerating voltage of $5 \mathrm{kV}$.

\section{XRD and TGA}

Crystal samples were ground to a fine powder using a clean ceramic mortar and pestle and compacted tightly on the reverse side of an aluminium specimen holder $(15 \times 20 \times$ $2 \mathrm{~mm}^{3}$ ), which was held against a glass side and detached after the back cover was snapped into place. The mineral phase of the crystals was identified using a Hiltonbrooks Xray diffractometer (HiltonBrooks Ltd., Crewe, UK) equipped with a single graphite crystal monochromatic $\mathrm{CuK} \alpha$ chronometer $(30 \mathrm{~mA}, 40 \mathrm{kV})$. Duplicate samples were analysed over the range of $3-60^{\circ} 2 \theta$ angle at a scan rate of one degree per min in $0.1^{\circ}$ increments.

TGA of the crystal samples was carried out using a NETZSCH STA 409PC TG/DTG/DTA analyser fitted with a SiC furnace (NETZSCH Group, Selb, Germany). Small amounts $(<100 \mathrm{mg})$ of crystals were heated to $1000{ }^{\circ} \mathrm{C}$ at a heating rate of $10 \mathrm{~K} \mathrm{~min}^{-1}$ using dry $\mathrm{N}_{2}$ as a purge gas at a flow rate of $100 \mathrm{~cm}^{3} \mathrm{~min}^{-1}$. The samples were maintained at $1000{ }^{\circ} \mathrm{C}$ until constant weight. A curve of mass loss as a function of temperature was created as the result. After thermal treatment, all samples were collected for XRD analysis to identify the presence of possible mineral phases.

\section{Statistical analysis}

One-way ANOVA was applied using Tukey's test to compare means of growth rate, biomass yield, and surface $\mathrm{pH}$ at a significance level of 0.05 between samples from the same medium treated with different concentrations of lanthanum.

\section{Results}

\section{Fungal growth and crystal formation}

Measurement of colony diameters was discontinued on the 6th day of growth when the A. niger colonies reached the edge of the plate. A. niger grew on La-free MCD plates at an average rate of $14.21 \pm 0.46 \mathrm{~mm} \mathrm{day}^{-1}$ which was not significantly influenced $(p<0.05)$ by the presence of 1 and $5 \mathrm{mM} \mathrm{LaCl}_{3}$. However, at $10 \mathrm{mM} \mathrm{LaCl}_{3}$, the growth rate was reduced approximately by $25 \%$ compared with the control. Biomass yield decreased slightly from $0.19 \pm$ 0.01 to $0.17 \pm 0.01 \mathrm{~g}$ dry $\mathrm{wt}$ as the La concentration increased (Fig. 1). The agar surface $\mathrm{pH}$ was $\mathrm{pH} 1.86 \pm 0.04$ for the La-free control and $\mathrm{pH} 1.71 \pm 0.04$ for the $10 \mathrm{mM}$ La plates. The most prominent decrease in the tolerance index occurred at $5 \mathrm{mM} \mathrm{La}$, where the biomass yield was lowered by $12.4 \%$ (Table 1 ).

Obvious precipitation of white-coloured minerals was confirmed using light microscopy after 2 weeks of A. niger growth on MCD plates amended with $0,1,5$ and $10 \mathrm{mM} \mathrm{LaCl}_{3}$ (Fig. 2a-c). It was observed that the quantity of precipitates increased with higher $\mathrm{LaCl}_{3}$ concentrations resulting in larger single crystals which appeared to be formed by continuous growth with branches ramifying in all directions with final sizes varying from approximately 300 to more than $1000 \mu \mathrm{m}$ in length across three La concentrations (Fig. 2d-f).

\section{SEM and EDXA}

Mycogenic crystals from MCD plates containing $1 \mathrm{mM}$ $\mathrm{LaCl}_{3}$ were recovered after 14-day fungal growth and

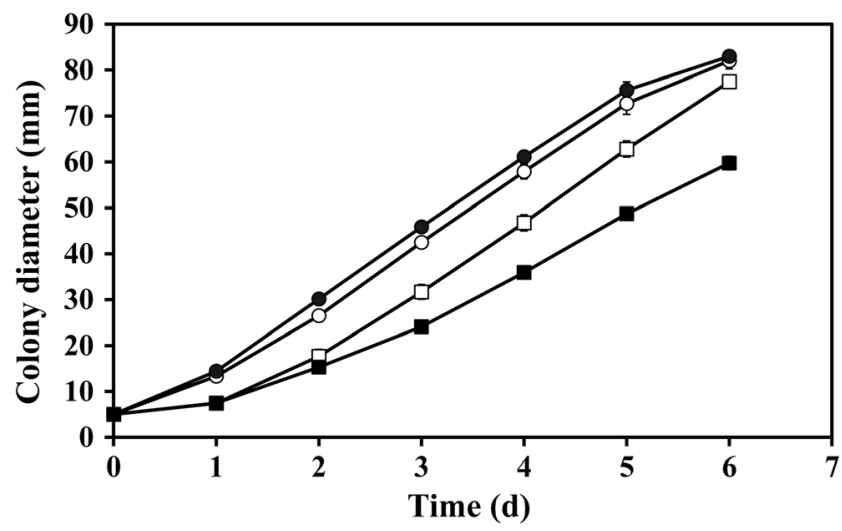

Fig. 1 Colony expansion rate of $A$. niger on solid Czapek-Dox media containing $0 \mathrm{mM}$ (empty circle), $1 \mathrm{mM}$ (filled circle), $5 \mathrm{mM}$ (empty square) and $10 \mathrm{mM}$ (filled square) $\mathrm{LaCl}_{3}$ over 6-day incubation at $25{ }^{\circ} \mathrm{C}$ in the dark. Data are averages of at least three replicates with error bars (shown only when greater than symbol dimensions) showing the standard error of the mean 
Table 1 Growth rate, biomass yield, agar surface $\mathrm{pH}$ and tolerance index (TI) of $A$. niger after 14-day growth at $25^{\circ} \mathrm{C}$ in the dark in solid Czapek-Dox medium supplemented with lanthanum chloride

\begin{tabular}{lllll}
\hline La concentration $(\mathrm{mM})$ & Growth rate $\left(\mathrm{mm} \mathrm{day}^{-1}\right)$ & Biomass $(\mathrm{g}$ dry wt) & Surface $\mathrm{pH}$ & TI (\%) \\
\hline 0 & $14.21 \pm 0.46 \mathrm{a}$ & $0.19 \pm 0.01 \mathrm{a}$ & $1.86 \pm 0.04 \mathrm{~b}$ & 100 \\
1 & $14.12 \pm 0.11 \mathrm{a}$ & $0.18 \pm 0.05 \mathrm{a}$ & $2.00 \pm 0.04 \mathrm{a}$ & 99.0 \\
5 & $14.31 \pm 0.21 \mathrm{a}$ & $0.16 \pm 0.01 \mathrm{a}$ & $1.87 \pm 0.03 \mathrm{~b}$ & 87.6 \\
10 & $10.67 \pm 0.33 \mathrm{~b}$ & $0.17 \pm 0.01 \mathrm{a}$ & $1.71 \pm 0.04 \mathrm{c}$ & 92.1 \\
\hline
\end{tabular}

Tolerance index (TI) was calculated according to the following formula: TI = (dry weight of La-exposed biomass/ dry weight of control biomass $\times 100 \%$ ). Data are given as means \pm SD from three independent replicates; different lowercase letters in each column indicate the significance level at $p<0.05$ subjected to SEM. After the homogenization and washing processes, the large single crystal structures were disrupted into dendritic fragments measuring approximately $500 \times$ $50 \mu \mathrm{m}$, and showing a layered texture (Fig. 3a, b). In contrast, crystals precipitated by an abiotic chemical reaction using pure oxalic acid and $\mathrm{LaCl}_{3}$ (Fig. 3c, d) consisted of only smooth crystal structures that did not show a layered pattern and were smaller $(40 \times 10 \mu \mathrm{m})$ than the mycogenic preparations. EDXA identified the main elements in the mycogenic crystals produced in solid (Fig. 4a) and liquid (Fig. 4b) media as C, O and La. The EDX spectra showed distinguishable peaks which matched well with the characteristic pattern of lanthanum at 0.833 and $4.650 \mathrm{keV}$. However, a phosphorus peak at $2.013 \mathrm{keV}$ was evident in some samples produced from liquid reactions at high $\mathrm{La}$ concentrations (Fig. 4c).

\section{XRD analysis}

The XRD pattern for the biogenic samples showed a wellformed crystalline structure with the peaks matching well with the standard pattern for $\mathrm{La}_{2}\left(\mathrm{C}_{2} \mathrm{O}_{4}\right)_{3} \cdot 10 \mathrm{H}_{2} \mathrm{O}$ (JCPDS card no. 20-549) in the database (Fig. 5a). Therefore, the mycogenic crystals were conclusively identified as lanthanum oxalate decahydrate.

\section{Thermal decomposition analysis}

Thermogravimetric experiments recorded a stepwise thermal decomposition course for the mycogenic crystals, which was identical with that of abiotic controls. The decomposition process consisted of three stages commencing with an initial $22.6 \%$ weight loss from 45 to
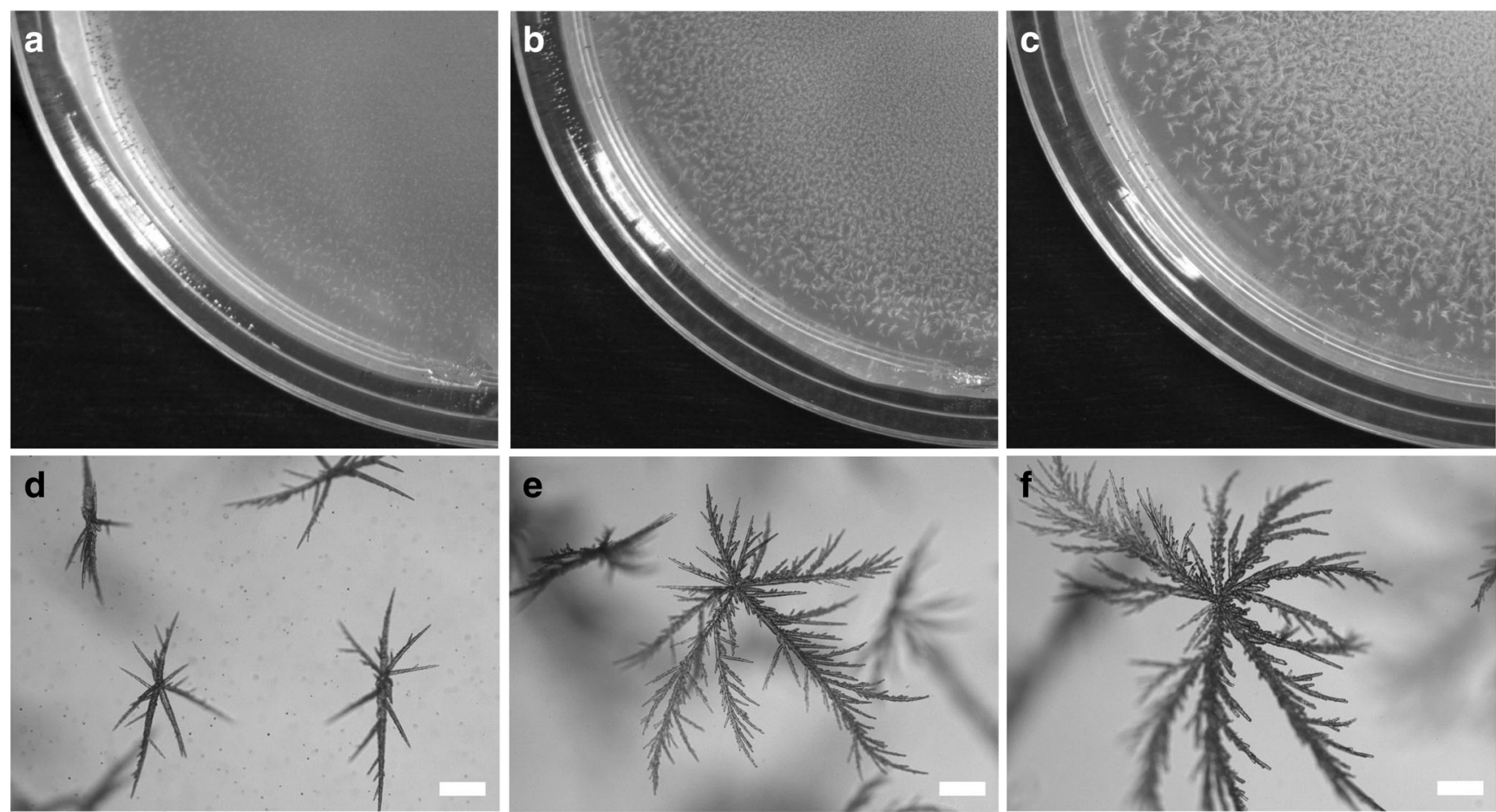

Fig. 2 Formation of crystals in solid Czapek-Dox medium after 2 weeks incubation of A. niger at $25^{\circ} \mathrm{C}$ in the dark. Plates were supplemented with a, d $1 \mathrm{mM}, \mathbf{b}, \mathbf{e} 5 \mathrm{mM}$ and $\mathbf{c}, \mathbf{f} 10 \mathrm{mM} \mathrm{LaCl}_{3}$. (d-f, scale bars $\left.=100 \mu \mathrm{m}\right)$. Typical images are shown from several similar examinations 
Fig. 3 Scanning electron microscopy of $\mathbf{a}, \mathbf{b}$ mycogenic crystals purified from $1 \mathrm{mM} \mathrm{La}-$ containing Czapek-Dox medium after 14-day incubation at $25^{\circ} \mathrm{C}$ in the dark with $A$. niger and $\mathbf{c}, \mathbf{d}$ crystals from chemical reaction of $25 \mathrm{mM}$ oxalic acid and $1 \mathrm{mM}$ lanthanum chloride. (a-c, scale bars $=50 \mu \mathrm{m} ; \mathbf{d}$, scale bar $=$ $5 \mu \mathrm{m})$. Typical images are shown from several similar examinations
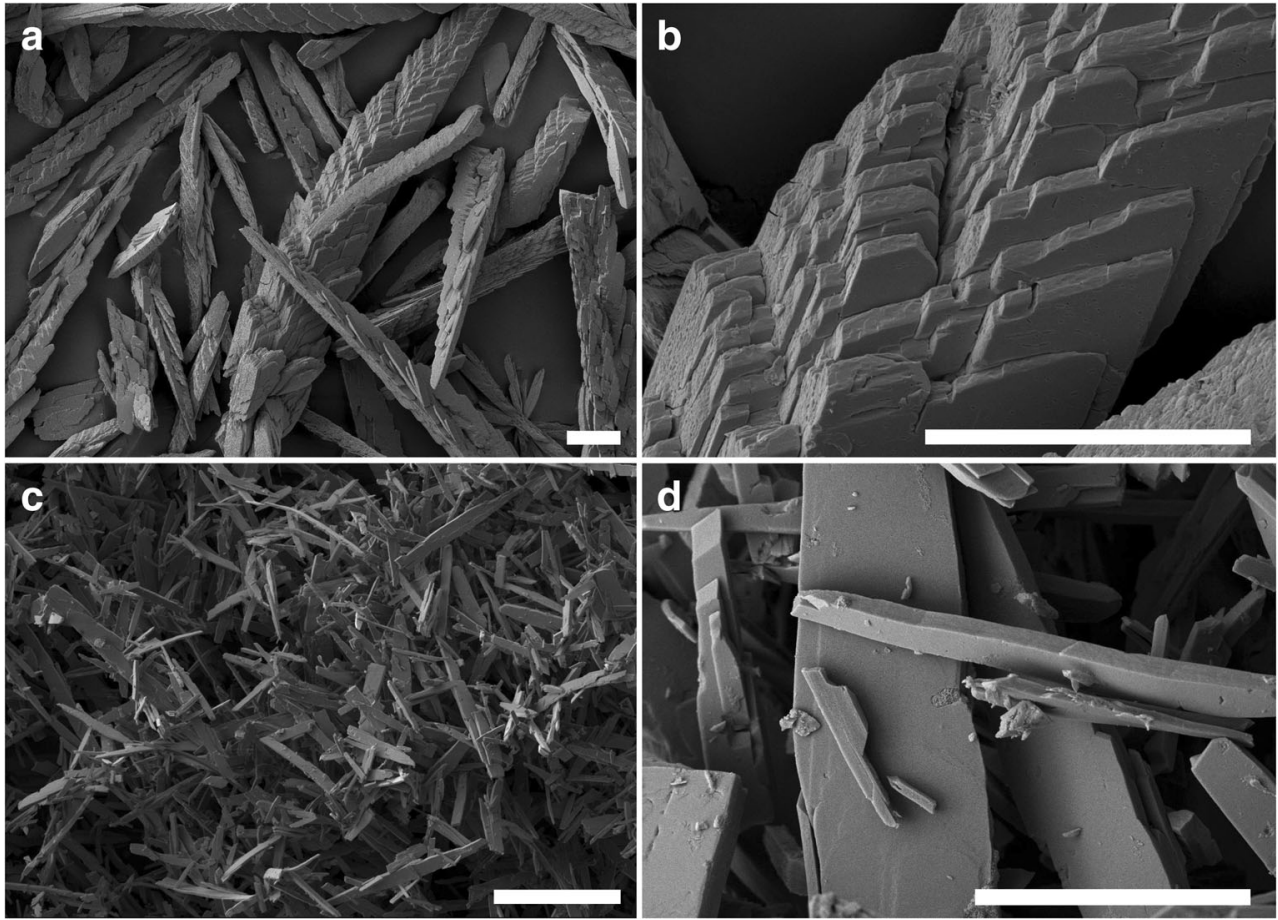

$250{ }^{\circ} \mathrm{C}$, followed by $33.0 \%$ from 400 to $600{ }^{\circ} \mathrm{C}$ and $11.8 \%$ from 710 to $800{ }^{\circ} \mathrm{C}$ until the weight remained constant (Fig. 6). The total mass loss amounted to $54.6 \%$ at above $800{ }^{\circ} \mathrm{C}$. The XRD pattern of the sample after complete thermal decomposition showed a high match with the standard pattern for $\mathrm{La}_{2} \mathrm{O}_{3}$ (JCPDS card no. 22-369) (Fig. 5b).

\section{Biomass-free culture supernatant experiments}

Reactions using mycogenic supernatants were performed using supernatants obtained from shaken liquid cultures of A. niger grown for 1 week in $\mathrm{NO}_{3}{ }^{-}$-containing AP1 medium. The $\mathrm{pH}$ of the supernatant had dropped to $\mathrm{pH} 3.41$ \pm 0.10 upon harvest. Large amounts of white precipitates were formed as a result of the $24 \mathrm{~h}$ reaction between $\mathrm{LaCl}_{3}$ and culture supernatants on the rotary shaker. At lower La concentrations, the precipitates were obviously granular and quickly settled at the tube bottom while at higher concentrations, they appeared to be smaller and formed a suspension. The production yield of precipitates from the $10-\mathrm{ml}$ reaction system increased from $4.2 \mathrm{mg}$ dry wt at $1 \mathrm{mM}$ La to $23.3 \mathrm{mg}$ dry wt at $15 \mathrm{mM}$ $\mathrm{La}$, which was the maximum yield observed. At concentrations higher than $15 \mathrm{mM} \mathrm{La}$, the yield was slightly reduced to $23 \mathrm{mg}$ at $20 \mathrm{mM} \mathrm{La}, 21.7 \mathrm{mg}$ at $30 \mathrm{mM} \mathrm{La}$, $20.8 \mathrm{mg}$ at $40 \mathrm{mM} \mathrm{La}$ and $19.4 \mathrm{mg}$ at $50 \mathrm{mM} \mathrm{La}$. The $\mathrm{pH}$, which was negatively correlated with increasing concentration of La, decreased from $\mathrm{pH} 3.40$ at $1 \mathrm{mM}$ La to $\mathrm{pH} 2.07$ at $50 \mathrm{mM}$ La. However, the decrease in $\mathrm{pH}$ was most prominent within the range 1 to $15 \mathrm{mM} \mathrm{La}$ and tended to remain unchanged at concentrations above $15 \mathrm{mM} \mathrm{La}$ (Fig. 7a). The percent removal of La was $100 \%$ with 1,3 and $5 \mathrm{mM} \mathrm{LaCl}_{3}$ in the reaction system but was reduced at higher $\mathrm{LaCl}_{3}$ concentrations: $94.0 \%$ at $7 \mathrm{mM} \mathrm{La}, 65.5 \%$ at $11 \mathrm{mM} \mathrm{La}, 49.8 \%$ at $15 \mathrm{mM} \mathrm{La}$, $37.1 \%$ at $20 \mathrm{mM} \mathrm{La}, 21.9 \%$ at $30 \mathrm{mM} \mathrm{La}, 11.9 \%$ at $40 \mathrm{mM} \mathrm{La}$ and $10.1 \%$ at $50 \mathrm{mM} \mathrm{La}$. The maximum amount of $\mathrm{La}(74.8 \mu \mathrm{mol})$ was removed at $15 \mathrm{mM} \mathrm{La}$ (Fig. 7c). The kinetics of La removal showed a high similarity with those of precipitation yield.

Control experiments were carried out using $25 \mathrm{mM}$ oxalic acid solution reacted with solutions of $\mathrm{LaCl}_{3}$. It was found that the precipitation yield in the control group also showed an increase with rising La concentrations until $15 \mathrm{mM}$ La where the maximum yield of $53.3 \mathrm{mg}$ dry $\mathrm{wt}$ was reached. A similar trend of $\mathrm{pH}$ change was found for the control which declined from $\mathrm{pH} 1.77$ at $1 \mathrm{mM}$ La to pH 1.43 at $15 \mathrm{mM} \mathrm{La} \mathrm{(Fig.} \mathrm{7b).} \mathrm{The} \mathrm{amount} \mathrm{of} \mathrm{removed}$ $\mathrm{La}$, which reached $146.5 \mathrm{mg}$ dry $\mathrm{wt}$, was only slightly lower than the maximum of $149.7 \mathrm{mg}$ dry wt occurring at $20 \mathrm{mM}$ and showed almost a linear relationship to the lanthanum concentration over the range 1 to $15 \mathrm{mM} \mathrm{La}$. The removal rate was maintained at $100 \%$ until $11 \mathrm{mM} \mathrm{La}$ and slightly dropped to $97.7 \%$ at $15 \mathrm{mM}$ La before a marked decline at $20 \mathrm{mM} \mathrm{La}$ and above (Fig. 7d).

SEM showed that at low La concentration ( $1 \mathrm{mM} \mathrm{La})$, the crystals were of a relatively flat structure with smooth surfaces and measuring approximately $1 \mu \mathrm{m}$ in width and $10 \mu \mathrm{m}$ in length (Fig. 8a) and bore a close resemblance 


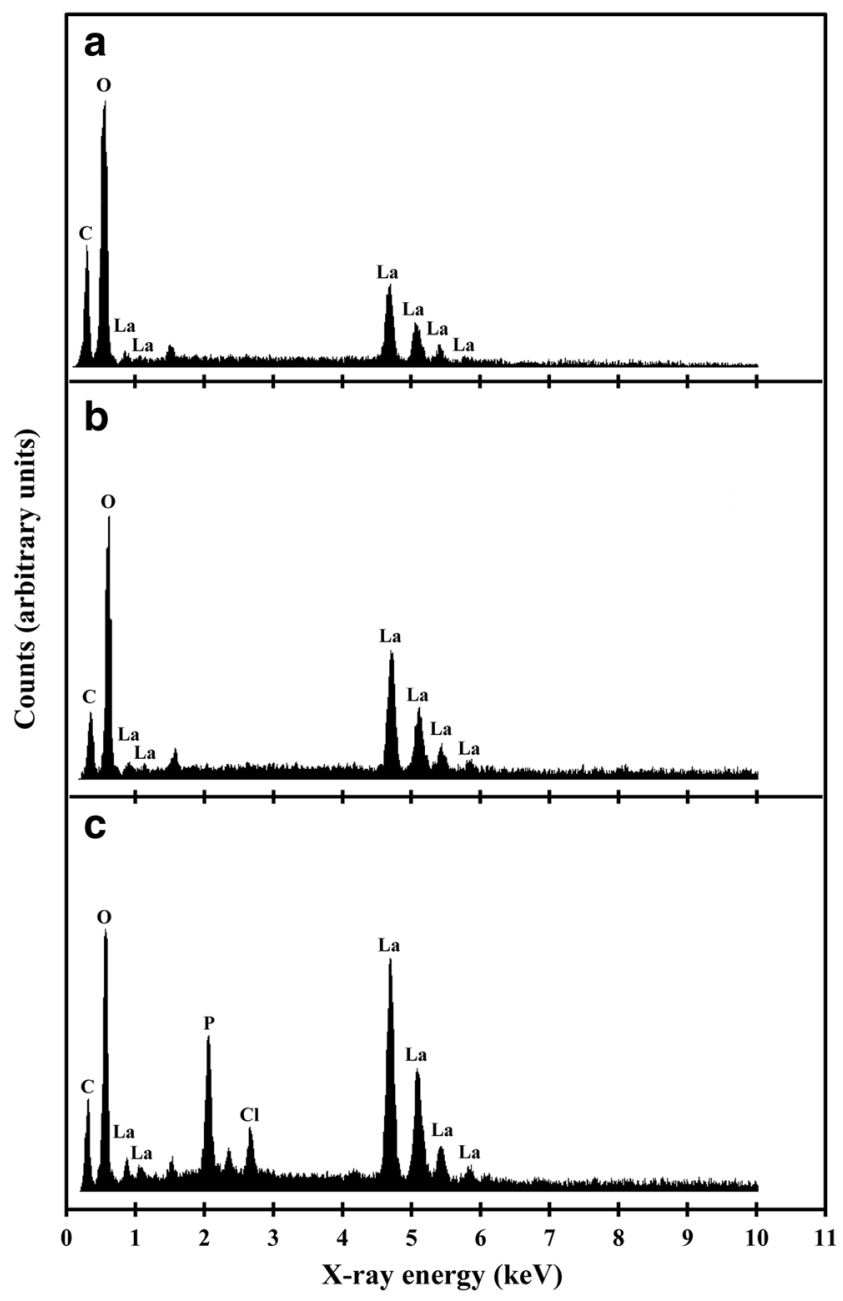

Fig. 4 Energy-dispersive X-ray analysis of (a) mycogenic crystals formed in solid Czapek-Dox medium containing $1 \mathrm{mM} \mathrm{LaCl}_{3}$ after incubation with $A$. niger for 14 days at $25{ }^{\circ} \mathrm{C}$ in the dark; EDXA of crystals precipitated by reactions of (b) $1 \mathrm{mM}$ and (c) $40 \mathrm{mM} \mathrm{LaCl}_{3}$ with biomass-free culture supernatant of $\mathrm{NO}_{3}{ }^{-}$-containing AP1 medium that was incubated with $A$. niger for 7 days at $25^{\circ} \mathrm{C}$ in the dark. Typical spectra are shown from several similar determinations

with those precipitated in the abiotic chemical reactions (Fig. 3d). At a medium La concentration (7 mM La), the crystals were larger in size and their surfaces were associated with small fragments of irregular shape (Fig. 8b). Aggregates of spherical minerals appeared, and the amount of tabular-shaped single crystals decreased at $20 \mathrm{mM} \mathrm{La}$ and above (Fig. 8c, d). All these spherical structures were of the same size measuring less than $1 \mu \mathrm{m}$ in diameter. The mineral samples produced at both lower and higher La concentrations were subjected to further examination using EDXA and XRD. EDXA of samples obtained at higher La levels showed the presence of phosphorus, which was further confirmed by XRD showing well-matched patterns for both $\mathrm{La}_{2}\left(\mathrm{C}_{2} \mathrm{O}_{4}\right)_{3} \cdot 10 \mathrm{H}_{2} \mathrm{O}$ and the P-containing mineral $\mathrm{La}_{7} \mathrm{P}_{3} \mathrm{O}_{8}$ (Fig. 9).

\section{Geochemical modelling}

The geochemical model for the solid medium experiments was constructed with the assumption that the system contained $1 \mathrm{mM} \mathrm{LaCl}_{3}$ in order to simulate the formation of lanthanum oxalate by the secretion of mycogenic oxalic acid. The model for the liquid culture reactions was created to simulate the precipitation of the biominerals in the presence of $25 \mathrm{mM}$ oxalic acid, a realistic value to be released by A. niger (Ceci et al. 2015b). The results showed there was a difference in mineral phase speciation in both solid and liquid media. In solid medium, where lanthanum oxalate was the only solid phase in the modelled system, $\mathrm{La}_{2}\left(\mathrm{C}_{2} \mathrm{O}_{4}\right)_{3}$ could be formed over the range $0<\mathrm{pH}<2.39$ if the concentration of $\left(\mathrm{C}_{2} \mathrm{O}_{4}\right)^{2-}$ was above $10^{-1.15} \mathrm{M}$ and at $\mathrm{pH}>2.39$ when the $\left(\mathrm{C}_{2} \mathrm{O}_{4}\right)^{2-}$ concentration was above $10^{-4.78} \mathrm{M}$ (Fig. 10a). In the liquid reaction systems, in addition to $\mathrm{La}_{2}\left(\mathrm{C}_{2} \mathrm{O}_{4}\right)_{3}, \mathrm{LaPO}_{4}$ could be precipitated when the $\mathrm{pH}$ was above $\mathrm{pH} 3.63$ and the $\mathrm{La}^{3+}$ concentration no less than $10^{-5.77} \mathrm{M}$ (Fig. 10b).

\section{Discussion}

Despite the chemical properties and characteristics of lanthanum and its compounds being well-studied in a chemical context, its interactions with microorganisms have received scant attention. Our work, for the first time, has demonstrated the formation of insoluble biogenic lanthanum oxalate by fungi and has therefore offered an insight into possible future biotechnological applications for the biorecovery of lanthanides and other rare earths and metals (Liang and Gadd 2017). Growth of A. niger in solid medium was only slightly affected by even high concentrations $(>10 \mathrm{mM})$ of lanthanum and the formation of large amounts of crystals was achieved, demonstrating the high efficiency of the process. This work has therefore laid a foundation for the biorecovery of REE using mycogenic oxalic acid. Crystals of lanthanum oxalate precipitated under chemical conditions usually carry 10.2 molecules of water and have a well-formed monoclinic crystal habit with clinopinacoid $(0,1,0)$ (where the crystal plane is parallel to the vertical and the inclined lateral axes), orthopinacoid $(1,0,0)$ (with crystal planes parallel to the orthodiagonal and vertical axes) and clinodome $(0,1,1)$ (a dome in which the planes are parallel to the inclined axis) structures (Gilphin and McCrone 1952), which is in agreement with the morphological features of our samples produced at high La concentrations (Fig. 8c, d). The morphology of abiotic REE oxalates can also vary according to the methods and conditions applied to the precipitation reaction. Flower-like 
Fig. 5 X-ray diffraction of (a) mycogenic crystals obtained from solid Czapek-Dox medium containing $1 \mathrm{mM} \mathrm{LaCl} 3$ and incubated with $A$. niger for 14 days at $25{ }^{\circ} \mathrm{C}$ in the dark; (b) XRD of the above-mentioned sample after thermogravimetric treatment at $1000{ }^{\circ} \mathrm{C}$ until constant weight. The standard patterns shown below the XRD patterns are (a) lanthanum oxalate decahydrate (JCPDS card no. 20549) and (b) lanthanum oxide (JCPDS card no. 05-602). Typical patterns are shown from several similar determinations

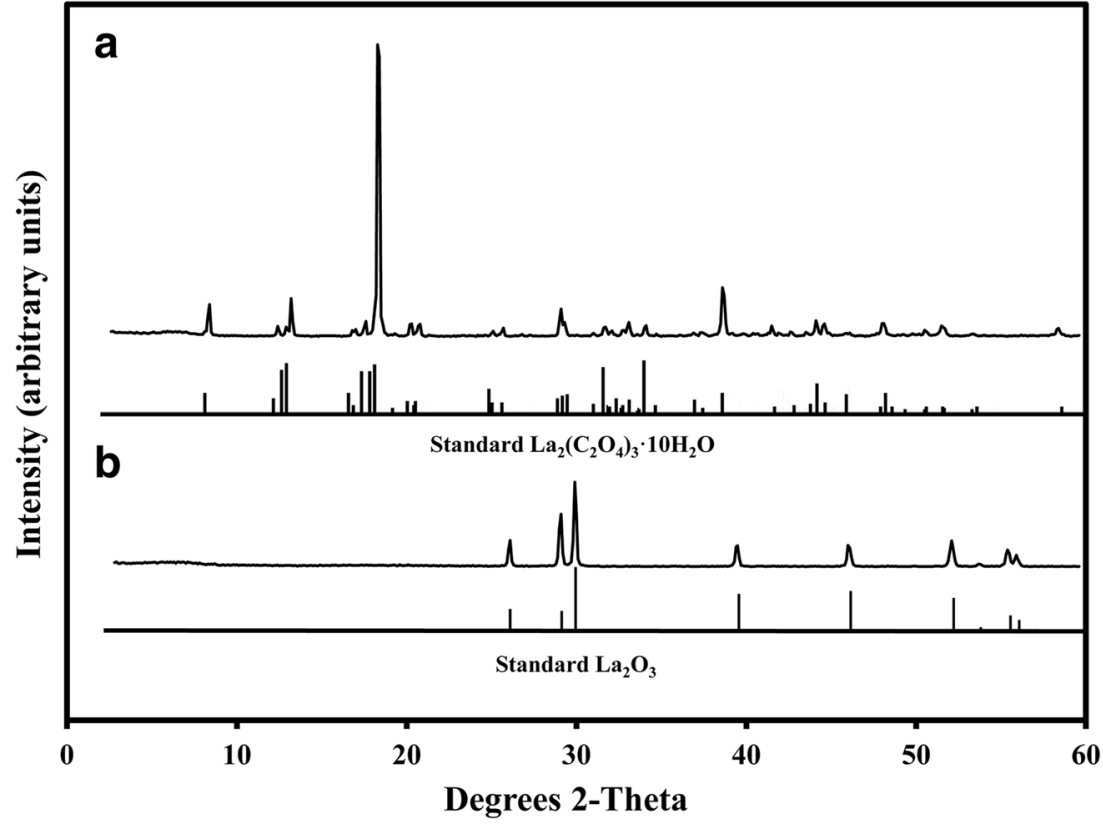

hierarchical microparticles, which showed similarity to those obtained in our work, were formed when $\mathrm{La}_{2}\left(\mathrm{C}_{2} \mathrm{O}_{4}\right)_{3} \cdot 10 \mathrm{H}_{2} \mathrm{O}$ was precipitated at room temperature in the presence of sodium citrate, and nanotubes were produced using a mixed solvent of water and ethanol in a 1:1 ratio (Zhang et al. 2014).

Thermogravimetric analysis is a useful tool to investigate the thermal properties of crystals as well as their structure and characterizes the thermal decomposition of biominerals (Balboul et al. 2002). Chlorides of REE are highly soluble in water and can be precipitated as oxalates, which may be further converted into oxides by ignition at $800{ }^{\circ} \mathrm{C}$ (Kolthoff and Elmquist 1931). The biogenic lanthanum oxalate crystals produced in the work underwent three stages of decomposition resulting in a total mass change of $54.6 \%$, which is consistent with theoretical data (54.8\%) based on calculations of the stepwise decomposition course as follows (Balboul et al. 2002) with lanthanum oxide $\left(\mathrm{La}_{2} \mathrm{O}_{3}\right)$ being the final product:

$$
\begin{aligned}
& \mathrm{La}_{2}\left(\mathrm{C}_{2} \mathrm{O}_{4}\right)_{3} \cdot 10 \mathrm{H}_{2} \mathrm{O} \rightarrow \mathrm{La}_{2}\left(\mathrm{C}_{2} \mathrm{O}_{4}\right)_{3} \cdot 4 \mathrm{H}_{2} \mathrm{O}+6 \mathrm{H}_{2} \mathrm{O} \\
& E_{a}=65.47 \mathrm{~kJ} \mathrm{~mol}^{-1} \\
& \mathrm{La}_{2}\left(\mathrm{C}_{2} \mathrm{O}_{4}\right)_{3} \cdot 4 \mathrm{H}_{2} \mathrm{O} \rightarrow \mathrm{La}_{2}\left(\mathrm{C}_{2} \mathrm{O}_{4}\right)_{3} \cdot 2 \mathrm{H}_{2} \mathrm{O}+2 \mathrm{H}_{2} \mathrm{O} \\
& E_{a}=106.90 \mathrm{~kJ} \mathrm{~mol}^{-1} \\
& \mathrm{La}_{2}\left(\mathrm{C}_{2} \mathrm{O}_{4}\right)_{3} \cdot 2 \mathrm{H}_{2} \mathrm{O} \rightarrow \mathrm{La}_{2}\left(\mathrm{C}_{2} \mathrm{O}_{4}\right)_{3}+2 \mathrm{H}_{2} \mathrm{O} \\
& E_{a}=120.90 \mathrm{~kJ} \mathrm{~mol}^{-1}
\end{aligned}
$$

Fig. 6 Thermogravimetric analysis of mycogenic crystals obtained from solid Czapek-Dox medium amended with $1 \mathrm{mM}$ $\mathrm{LaCl}_{3}$ and incubated with $A$. niger for 14 days at $25^{\circ} \mathrm{C}$ in the dark. DTG denotes differential thermal gravimetry, which is expressed as percentage of weight loss per minute. A typical pattern is shown from several similar determinations, all of which gave similar results

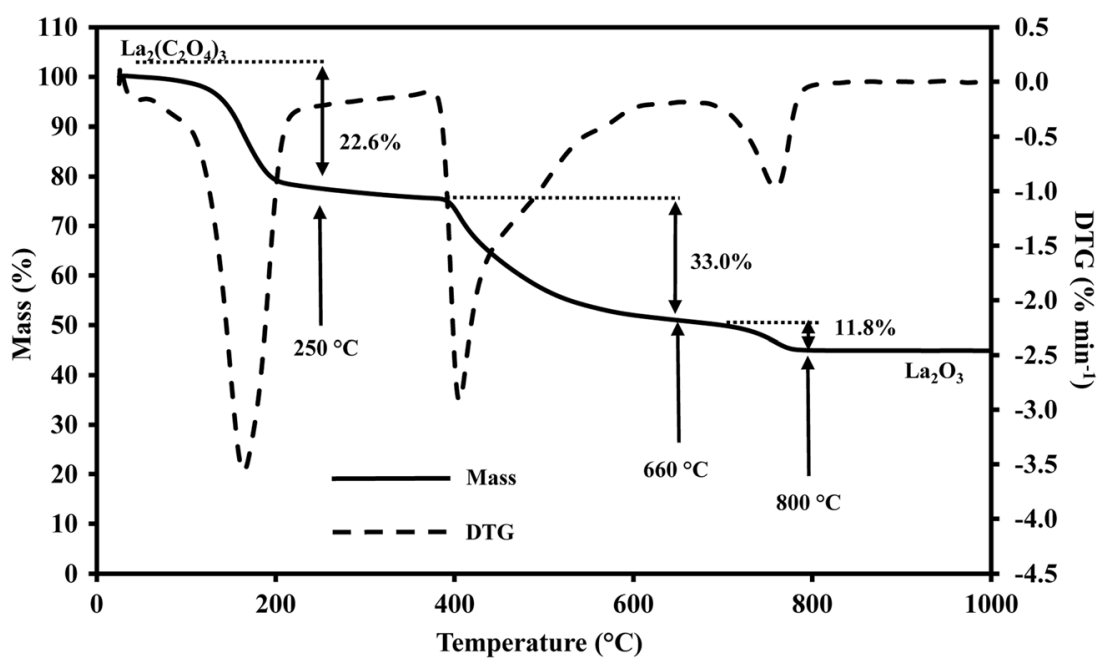



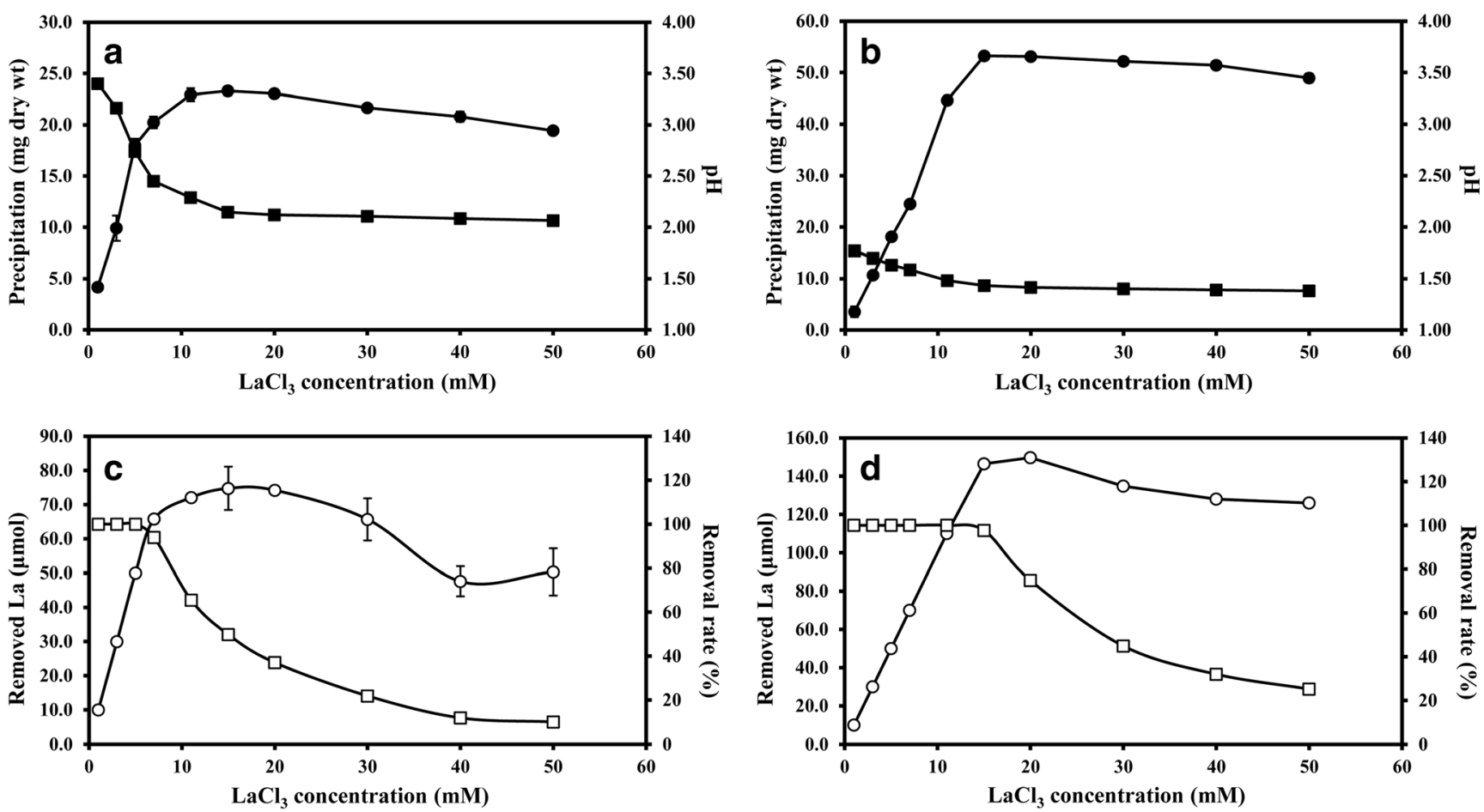

Fig. 7 a Precipitation yield and $\mathbf{c}$ La removal rates for reactions of $1 \mathrm{ml}$ $\mathrm{LaCl}_{3}$ and $9 \mathrm{ml}$ biomass-free supernatant of $\mathrm{NO}_{3}{ }^{-}$-AP1 medium which was incubated with $A$. niger for 7 days at $25^{\circ} \mathrm{C}$ in the dark. b Precipitation yield and $\mathbf{d}$ La removal rates for chemical reactions of $9 \mathrm{ml} 25 \mathrm{mM}$ oxalic acid with $1 \mathrm{ml} \mathrm{LaCl}_{3}$. The amount of $\mathrm{La}$ removed after liquid reactions

$$
\begin{aligned}
& \mathrm{La}_{2}\left(\mathrm{C}_{2} \mathrm{O}_{4}\right)_{3} \rightarrow \mathrm{La}_{2} \mathrm{O}_{2} \mathrm{CO}_{3}+3 \mathrm{CO} \uparrow+2 \mathrm{CO}_{2} \uparrow \\
& E_{a}=177.68 \mathrm{~kJ} \mathrm{~mol}^{-1}
\end{aligned}
$$

(empty circle); dry wt of precipitate (filled circle); removal rate of La (empty square); $\mathrm{pH}$ after reaction (filled square). All data are given as means of at least three independent replicates. Standard deviation is represented by error bars which are not shown when smaller than the symbols

$$
\mathrm{La}_{2} \mathrm{O}_{2} \mathrm{CO}_{3} \rightarrow \mathrm{La}_{2} \mathrm{O}_{3}+\mathrm{CO}_{2} \uparrow \quad E_{a}=156.4 \mathrm{~kJ} \mathrm{~mol}^{-1}
$$

where $E_{a}$ represents the energy of activation.

Fig. 8 Scanning electron microscopy of crystal samples from reactions of $\mathbf{a} 1, \mathbf{b} 7, \mathbf{c} 30$, and $\mathbf{d} 50 \mathrm{mM} \mathrm{LaCl}_{3}$ with biomass-free culture supernatant of $\mathrm{NO}_{3}{ }^{-}$-AP1 medium grown with $A$. niger for 7 days at $25^{\circ} \mathrm{C}$ in the dark. $(\mathbf{a}-\mathbf{d}$, scale bars $=$ $5 \mu \mathrm{m}$ ). Typical images are shown from several similar examinations
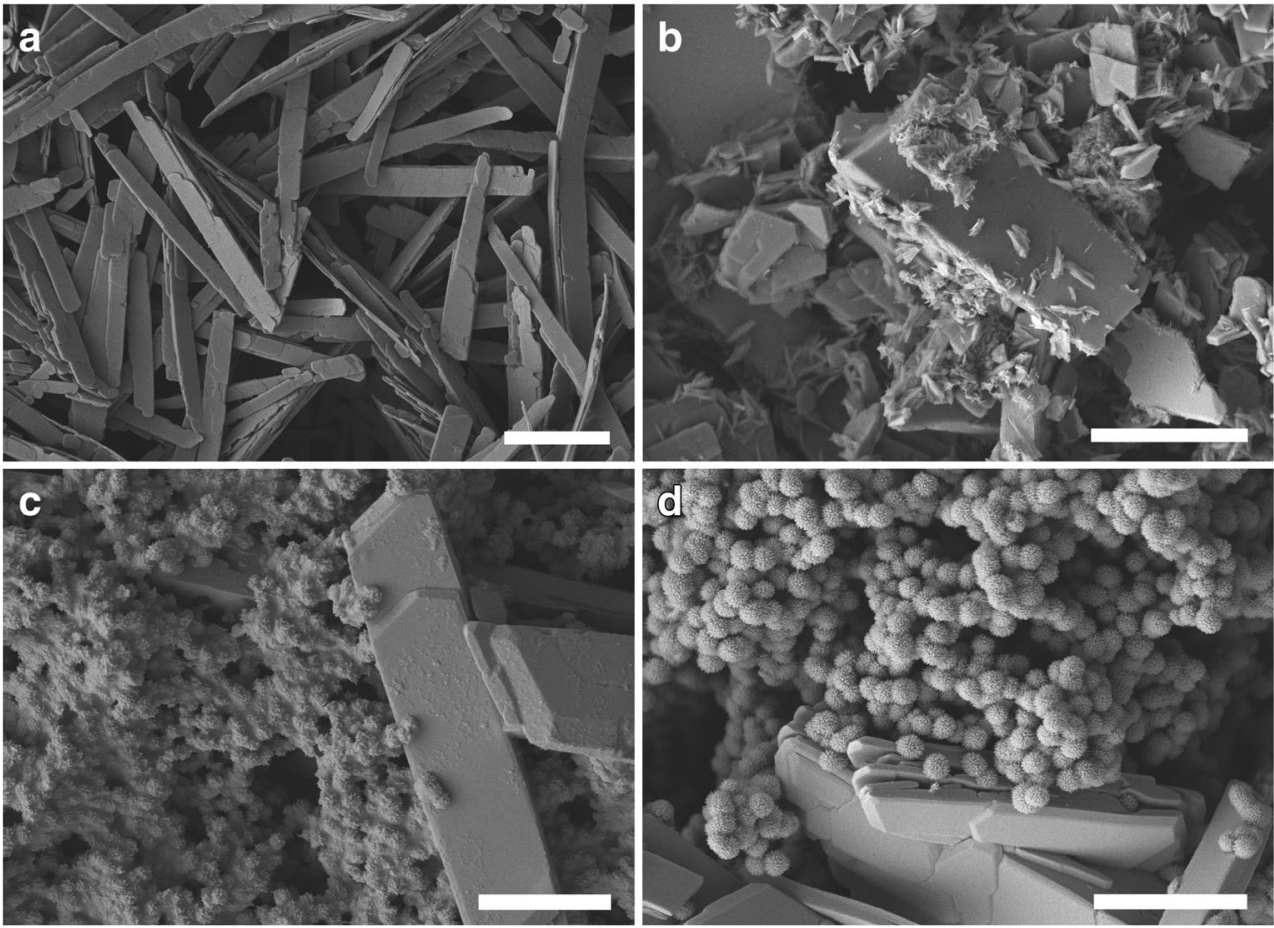
Fig. 9 X-ray diffraction of crystals from reaction of $20 \mathrm{mM}$ $\mathrm{LaCl}_{3}$ with biomass-free culture supernatant of $\mathrm{NO}_{3}{ }^{-}-\mathrm{AP} 1$ medium after incubation with A. niger for 7 days at $25^{\circ} \mathrm{C}$ in the dark. Standard patterns of $\mathrm{La}_{2}\left(\mathrm{C}_{2} \mathrm{O}_{4}\right)_{3} \cdot 10 \mathrm{H}_{2} \mathrm{O}$ and $\mathrm{La}_{7} \mathrm{P}_{3} \mathrm{O}_{18}$ are also shown. A typical result is shown from one of several similar determinations, all of which gave similar results

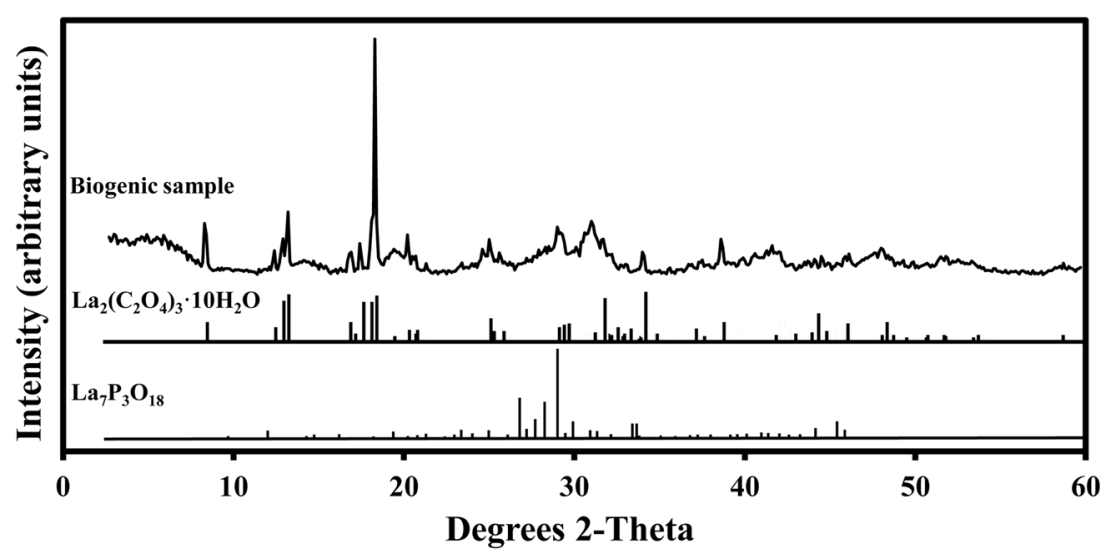

All five stages of thermal decomposition can generally be fitted to a kinetic function (Zhan et al. 2012):

$G(\alpha)=\left[1-(1+\alpha)^{1 / 3}\right]^{2}$

where $\alpha$ is the extent of thermal conversion dependent on $E_{a}$ and defined by the following equation:

$\alpha=\left(m_{0}-m\right) /\left(m_{0}-m_{\mathrm{f}}\right)$

where $m$ is the mass of the sample at a given time; $m_{0}$ and $m_{\mathrm{f}}$ refer to the mass at the beginning and the end of the thermal decomposition.

The temperature range and decomposition course generally corresponded with a previous study where $\mathrm{La}_{2}\left(\mathrm{C}_{2} \mathrm{O}_{4}\right)_{3} \cdot 10 \mathrm{H}_{2} \mathrm{O}$ was heated to $900{ }^{\circ} \mathrm{C}$ and a weight loss of $58.1 \%$ was recorded (Zhan et al. 2012). However, a step of $4.9 \%$ mass loss occurred at $226^{\circ} \mathrm{C}$, which was caused by the transformation of hexahydate to dihydrate, was not prominent here and a total loss of $22.6 \%$ upon reaching $250{ }^{\circ} \mathrm{C}$ was recorded. This work has therefore not only demonstrated a means to recover $\mathrm{La}$ as lanthanum oxalate but also that mycogenic lanthanum oxalate can serve as a precursor for the preparation of $\mathrm{La}_{2} \mathrm{O}_{3}$ which has significant catalytic properties and is of use in several industrial fields including biodiesel production, manufacture of optical glass, phosphate removal and antimicrobial substances (Johnson et al. 2005; Liu et al. 2017; Fang et al. 2018; Salinas et al. 2018).

As regards geomicrobial transformations of minerals, fungal-produced oxalic acid can play a role in the solubilization of several minerals including calcite and dolomite (Gadd 2017). Minerals containing, e.g. $\mathrm{Ca}, \mathrm{Cd}, \mathrm{Co}, \mathrm{Cu}, \mathrm{Mg}, \mathrm{Mn}, \mathrm{Sr}$, $\mathrm{Zn}, \mathrm{Ni}$ and $\mathrm{Pb}$ can be transformed into oxalates by interaction with oxalate-secreting fungi (Gadd 2007; Sullivan et al. 2012; Gadd et al. 2014). Many preceding studies involving the transformation of minerals by oxalic acid-producing fungi have focused on the bioprecipitation of calcium oxalate as whewellite and weddellite (Punja and Jenkins 1984; Gadd et al. 2014; Gadd 2017). One of our preliminary experiments using La-containing malt extract agar as a growth medium for A. niger also developed pyramid-shaped crystals with typical morphological characteristics of calcium oxalate amid lanthanum oxalate crystals (data not shown). Oxalic acid could be useful in the final steps of metallurgical processes to recovery REE from leachates or other solutions (Sinha et al. 2016). Chi et al. (2004) applied oxalic acid to precipitate total rare earth
Fig. 10 a Speciation diagram of $\mathrm{pH}$ versus $\log \left[\left(\mathrm{C}_{2} \mathrm{O}_{4}\right)^{2-}\right]$ in the presence of $1 \mathrm{mM} \mathrm{LaCl}_{3}$ and $\mathbf{b}$ $\mathrm{pH}$ vs $\log \left[\mathrm{La}^{3+}\right]$ in the presence of $25 \mathrm{mM}$ oxalic acid. All simulated reactions were set at $25^{\circ} \mathrm{C}$ under 1.013 bars atmosphere pressure, and the activities of all chemicals contained in the media were calculated using Geochemist's Workbench in accordance with their actual concentrations a

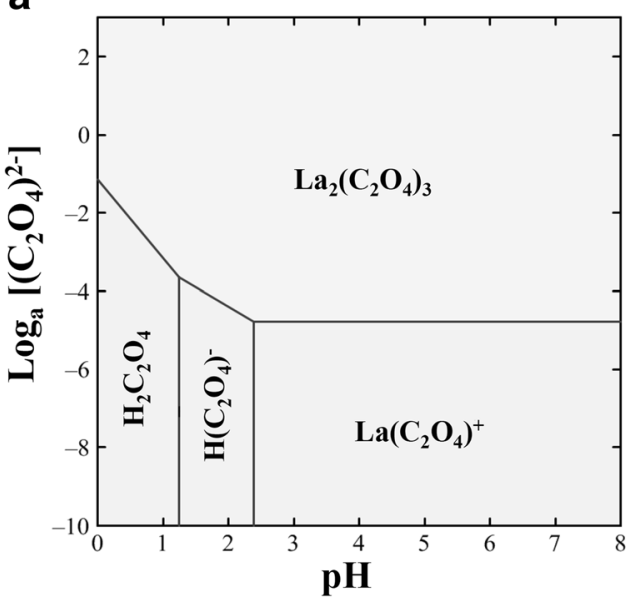

b

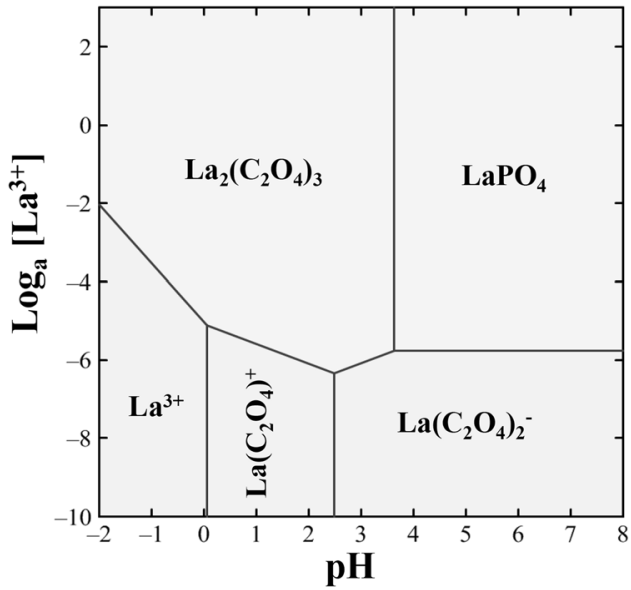


elements, including $\mathrm{Ce}$ and $\mathrm{La}$, from a leachate from bastnasite processing, and the produced oxalates were transformed into oxides after being roasted at $900{ }^{\circ} \mathrm{C}$ for $2 \mathrm{~h}$. A similar process was also reported in another study where oxalic acid was utilized to recover lanthanides from REEbearing phosphate rocks after being treated with strong acid (Aly and Mohammed 1999). Moreover, an appropriate amount of $\left(\mathrm{NH}_{4}\right)_{2} \mathrm{C}_{2} \mathrm{O}_{4}$ was successfully used to separate lanthanum from a leachate consisting of a mixture of elements extracted from spent Ni-Mn batteries (Fernandes et al. 2013). Our XRD results showed uniformity for all biogenic and control samples from both agar plates and liquid media reactions at $1 \mathrm{mM} \mathrm{La}$, confirming that the biominerals were wellformed crystalline structures of high purity as indicated by the sharp characteristic peaks matching impeccably with standard patterns for lanthanum oxalate in the database and a flat noise base.

In solid media experiments, only lanthanum oxalate crystals occurred even at high La concentrations. However, at higher La concentrations in the biomass-free liquid culture supernatant experiments, phosphorus was found in high amounts, associated with micro-sized spheres, indicating that P-containing compounds were also precipitated. This coincided well with the results of $\mathrm{pH}$ changes shown in the mass balance analysis at $\mathrm{pH} 3.40$ and $1 \mathrm{mM} \mathrm{La}$ and with the geochemical modelling which showed lanthanum oxalate speciation when below $\mathrm{pH}$ 3.63. The plateau occurring above $15 \mathrm{mM} \mathrm{La}$, as shown in the mass balance analysis, indicated that oxalic acid was depleted by excessive amounts of $\mathrm{La}^{3+}$, and any remaining La could participate in the precipitation of phosphates in the liquid media. It was reported that lanthanum phosphate, usually in the form of micro- or nano-sized particles and having a number of different mineral phases, could be produced by mixing $\mathrm{La}\left(\mathrm{NO}_{3}\right)_{3}$ and $\mathrm{H}_{3} \mathrm{PO}_{4}$ in a continuous precipitation reactor (Kawase et al. 2007). This could also account for the phosphates obtained at high La concentrations in our work. It is well known that fungi can release P from inorganic and organic sources which can therefore interact with other metals such as cadmium, cobalt, copper, lead, zinc and uranium, leading to the precipitation of secondary metal phosphates as microscale or nanoscale structures (Rhee et al. 2012, 2014; Gadd et al. 2014; Liang et al. 2015, 2016). In the present study, phosphates precipitated in the supernatant reaction system probably arose from chemical moieties in the growth medium according to the geochemical modelling where $\mathrm{LaPO}_{4}$ is formed if the system is $\mathrm{pH}>\sim 3.5$ in the presence of excessive amounts of $\mathrm{La}^{3+}$ (Fig. 10b). Therefore, the precipitation of P-containing biominerals could be caused by the presence of phosphates in the supernatant: by adjusting the $\mathrm{pH}$ and the volume of the lanthanum solution, the formation of lanthanum phosphates could be avoided.

In conclusion, the fungal transformation of lanthanum chloride into $\mathrm{La}_{2}\left(\mathrm{C}_{2} \mathrm{O}_{4}\right)_{3} \cdot 10 \mathrm{H}_{2} \mathrm{O}$, which can be subsequently converted into lanthanum oxide, is achievable by bioprecipitation in both La-containing solid media and biomass-free culture supernatants. Our study suggests a new biotechnological aspect for the biorecovery of rare earth elements.

Acknowledgements The authors thank Mr. Martin Kierans (Central Imaging Facility, School of Life Sciences, University of Dundee) and Dr. Yongchang Fan (Division of Physics, University of Dundee) for their assistance with scanning electron microscopy and Dr. Laszlo Csetenyi (Concrete Technology Group, Department of Civil Engineering, University of Dundee) for assistance with X-ray diffraction and thermogravimetric experiments.

Funding information Financial support of the Geomicrobiology Group is received from the Natural Environment Research Council [NE/M010910/ 1 (TeaSe); NE/M011275/1 (COG3)], which is gratefully acknowledged. Xia Kang acknowledges receipt of a School of Life Sciences PhD scholarship and sponsorship from the China Scholarship Council (No. 201606910077).

\section{Compliance with ethical standards}

Conflict of interest The authors declare that they have no conflict of interest.

Ethical approval This article does not contain any studies with human participants or animals performed by any of the authors.

Open Access This article is distributed under the terms of the Creative Commons Attribution 4.0 International License (http:// creativecommons.org/licenses/by/4.0/), which permits unrestricted use, distribution, and reproduction in any medium, provided you give appropriate credit to the original author(s) and the source, provide a link to the Creative Commons license, and indicate if changes were made.

\section{References}

Aly MM, Mohammed NA (1999) Recovery of lanthanides from Abu Tartur phosphate rock, Egypt. Hydrometall 52:199-206

Amin MM, El-Aassy IE, El-Feky MG, Sallam AM, El-Sayed EM, Nada AA, Harpy NM (2014) Fungal leaching of rare earth elements from lower carboniferous carbonaceous shales, southwestern Sinai, Egypt. Rom J Biophys 24:25-41

Ayora C, Macías F, Torres E, Lozano A, Carrero S, Nieto J-M, PérezLópez R, Fernández-Martínez A, Castillo-Michel H (2016) Recovery of rare earth elements and yttrium from passiveremediation systems of acid mine drainage. Environ Sci Technol 50:8255-8262

Balboul BAA, El-Roudi AM, Samir E, Othman AG (2002) Nonisothermal studies of the decomposition course of lanthanum oxalate decahydrate. Thermochim Acta 387:109-114

Barmettler F, Castelberg C, Fabbri C, Brandl H (2016) Microbial mobilization of rare earth elements (REE) from mineral solids - a mini review. AIMS Microbiology 2:190-204

Brisson VL, Zhuang W-Q, Alvarez-Cohen L (2016) Bioleaching of rare earth elements from monazite sand. Biotechnol Bioeng 113:339 348

Ceci A, Rhee YJ, Kierans M, Hillier S, Pendlowski H, Gray N, Persiani AM, Gadd GM (2015a) Transformation of vanadinite $\left(\mathrm{Pb}_{5}\left(\mathrm{VO}_{4}\right)_{3} \mathrm{Cl}\right)$ by fungi. Environ Microbiol 17:2018-2034 
Ceci A, Kierans M, Hillier S, Persiani AM, Gadd GM (2015b) Fungal bioweathering of mimetite and a general geomycological model for lead apatite mineral biotransformations. Appl Environ Microbiol 81: 4955-4964

Chi R, Zhang X, Zhu G, Zhou ZA, Wu Y, Wang C, Yu F (2004) Recovery of rare earth from bastnasite by ammonium chloride roasting with fluorine deactivation. Miner Eng 17:1037-1043

Currie JN (1917) The citric acid fermentation of Aspergillus niger. J Biol Chem 31:15-37

Desouky OA, El-Mougith AA, Hassanien WA, Awadalla GS, Hussien SS (2016) Extraction of some strategic elements from thorium-uranium concentrate using bioproducts of Aspergillus ficuum and Pseudomonas aeruginosa. Arab J Chem 9:S795-S805

Fang L, Wu B, Chan JKM, Lo IMC (2018) Lanthanum oxide nanorods for enhanced phosphate removal from sewage: a response surface methodology study. Chemosphere 192:209-216

Fernandes A, Afonso JC, Dutra AJB (2013) Separation of nickel (II), cobalt (II) and lanthanides from spent Ni-MH batteries by hydrochloric acid leaching, solvent extraction and precipitation. Hydrometall 133:37-43

Gadd GM (1999) Fungal production of citric and oxalic acid: importance in metal speciation, physiology and biogeochemical processes. Adv Microb Physiol 41:47-92

Gadd GM (2007) Geomycology: biogeochemical transformations of rocks, minerals, metals and radionuclides by fungi, bioweathering and bioremediation. Mycol Res 111:3-49

Gadd GM (2010) Metals, minerals and microbes: geomicrobiology and bioremediation. Microbiol 156:609-643

Gadd GM (2017) Fungi, rocks, and minerals. Elements 13:171-176

Gadd GM, Bahri-Esfahani J, Li QW, Rhee YJ, Wei Z, Fomina M, Liang XJ (2014) Oxalate production by fungi: significance in geomycology, biodeterioration and bioremediation. Fungal Biol Rev 28:36-55

Gilphin V, McCrone WC (1952) Crystallographic data. 52. Lanthanum oxalate decahydrate, $\mathrm{La}_{2}\left(\mathrm{C}_{2} \mathrm{O}_{4}\right)_{3} \cdot 10 \mathrm{H}_{2} \mathrm{O}$. Anal Chem 24:225-226

Goodenough KM, Wall F, Merriman D (2018) The rare earth elements: demand, global resources, and challenges for resourcing future generations. Nat Resour Res 27:201-216

Hassanien WAG, Desouky OAN, Hussien SSE (2013) Bioleaching of some rare earth elements from Egyptian monazite using Aspergillus ficuum and Pseudomonas aeruginosa. Walailak J Sci Technol 11:809-823

Hopfe S, Flemming K, Lehmann F, Möckel R, Kutschke S, Pollmann K (2017) Leaching of rare earth elements from fluorescent powder using the tea fungus Kombucha. Waste Manag 62:211-221

Humphries M (2010) Rare earth elements: the global supply chain. Congressional Research Service. The Library of Congress, Washington, DC

Ilyas S, Kim M-S, Lee J-C, Jabeen A, Bhatti HN (2017) Bio-reclamation of strategic and energy critical metals from secondary resources. Metals 7:207

Ismail Z, Abu Elgoud E, Gasser M, Aly H, Abdel Hai F, Ali I (2015) Leaching of some lanthanides from phosphogypsum fertilizers by mineral acids. Arab J Nucl Sci Appl 48:37-50

Ivanov VM, Ermakova NV (2001) Optical and chromaticity characteristics of Arsenazo III complexes of rare-earth elements. J Anal Chem 56:519-523

Johnson J, Weber R, Grimsditch M (2005) Thermal and mechanical properties of rare earth aluminate and low-silica aluminosilicate optical glasses. J Non-Cryst Solids 351:650-655

Kakushima K, Tsutsui K, Ohmi S-I, Ahmet P, Rao VR, Iwai H (2007) Rare earth oxides in microelectronics, $p$ 345-365. In: Fanciulli M, Scarel G (eds) Rare earth oxide thin films: topics in applied physics, vol 106. Springer, Berlin, Heidelberg
Kawase M, Suzuki T, Miura K (2007) Growth mechanism of lanthanum phosphate particles by continuous precipitation. Chem Eng Sci 62: 4875-4879

Keekan KK, Jalondhara JC, Abhilash (2017) Extraction of Ce and Th from monazite using REE tolerant Aspergillus niger. Min Proc Extr Metall Rev 38:312-320

Kilbourn BT (1987) The role of the lanthanides in the photonics, electronics and related industries. Inorg Chim Acta 140:335-338

Kolthoff IM, Elmquist R (1931) The solubilities of lanthanum oxalate and of lanthanum hydroxide in water. The mobility of the lanthanum ion at $25^{\circ}$. J Am Chem Soc 53:1217-1225

Kubicek CP, Rohr M (1985) Citric acid fermentation. Crit Rev Biotechnol 3:331-373

Leskelä M, Ritala M (2003) Rare-earth oxide thin films as gate oxides in MOSFET transistors. J Solid State Chem 171:170-174

Li Q, Gadd GM (2017) Biosynthesis of copper carbonate nanoparticles by ureolytic fungi. Appl Microbiol Biotechnol 101:7397-7407

Li Q, Csetenyi L, Paton GI, Gadd GM (2015) $\mathrm{CaCO}_{3}$ and $\mathrm{SrCO}_{3}$ bioprecipitation by fungi isolated from calcareous soil. Environ Microbiol 17:3082-3097

Liang X, Gadd GM (2017) Metal and metalloid biorecovery using fungi. Microb Biotechnol 10:1199-1205

Liang X, Hillier S, Pendlowski H, Gray N, Ceci A, Gadd GM (2015) Uranium phosphate biomineralization by fungi. Environ Microbiol 17:2064-2075

Liang X, Csetenyi L, Gadd GM (2016) Uranium bioprecipitation mediated by yeasts utilizing organic phosphorus substrates. Appl Microbiol Biotechnol 100:5141-5151

Liu J, Wang G, Lu L, Guo Y, Yang L (2017) Facile shape-controlled synthesis of lanthanum oxide with different hierarchical micro/ nanostructures for antibacterial activity based on phosphate removal. RSC Adv 7:40965-40972

Massari S, Ruberti M (2013) Rare earth elements as critical raw materials: focus on international markets and future strategies. Resource Policy 38:36-43

Mattey M (1992) The production of organic acids. Crit Rev Biotechnol 12:87-132

Papagianni M (2007) Advances in citric acid fermentation by Aspergillus niger: biochemical aspects, membrane transport and modeling. Biotechnol Adv 25:244-263

Park DM, Reed DW, Yung MC, Eslamimanesh A, Lencka MM, Anderko A, Fujita Y, Riman RE, Navrotsky A, Jiao Y (2016) Bioadsorption of rare earth elements through cell surface display of lanthanide binding tags. Environ Sci Technol 50:2735-2742

Patel A, Dawson R (2015) Recovery of platinum group metal value via potassium iodide leaching. Hydrometall 157:219-225

Preston JS, Cole PM, Craig WM, Feather AM (1996) The recovery of rare earth oxides from a phosphoric acid by-product. Part 1: leaching of rare earth values and recovery of a mixed rare earth oxide by solvent extraction. Hydrometall 41:1-19

Punja ZK, Jenkins SF (1984) Light and scanning electron microscopic observations of calcium oxalate crystals produced during growth of Sclerotium rolfsii in culture and in infected tissue. Can J Bot 62: 2028-2032

Qu Y, Li H, Tian W, Wang X, Wang X, Jia X, Shi B, Song G, Tang Y (2015) Leaching of valuable metals from red mud via batch and continuous processes by using fungi. Miner Eng 81:1-4

Reed DW, Fujita Y, Daubaras DL, Jiao Y, Thompson VS (2016) Bioleaching of rare earth elements from waste phosphors and cracking catalysts. Hydrometallurgy 166:34-40

Rhee YJ, Hillier S, Gadd GM (2012) Lead transformation to pyromorphite by fungi. Curr Biol 22:237-241

Rhee YJ, Hillier S, Pendlowski H, Gadd GM (2014) Pyromorphite formation in a fungal biofilm community growing on lead metal. Environ Microbiol 16:1441-1451 
Rohwer H, Collier N, Hosten E (1995) Spectrophotometric study of Arsenazo III and its interactions with lanthanides. Anal Chim Acta 314:219-223

Salinas D, Sepúlveda C, Escalona N, Gfierro JL, Pecchi G (2018) Sol-gel $\mathrm{La}_{2} \mathrm{O}_{3}-\mathrm{ZrO}_{2}$ mixed oxide catalysts for biodiesel production. J Energ Chem 27:565-572

Sayer JA, Gadd GM (1997) Solubilization and transformation of insoluble metal compounds to insoluble metal oxalates by Aspergillus niger. Mycol Res 101:653-661

Sayer JA, Raggett SL, Gadd GM (1995) Solubilization of insoluble metal compounds by soil fungi: development of a screening method for solubilizing ability and metal tolerance. Mycol Res 99:987-993

Schwartz W, Näveke R (1980) Biotechnische laugung armer erze mit heterotrophen mikroorganismen. Metall Jahrg 34:847-850

Sinha S, Abhilash MP, Pandey BD (2016) Metallurgical processes for the recovery and recycling of lanthanum from various resources - a review. Hydrometall 160:47-59

Sullivan TS, Gottel NR, Basta N, Jardine PM, Schadt CW (2012) Firing range soils yield a diverse array of fungal isolates capable of organic acid production and $\mathrm{Pb}$-mineral solubilization. Appl Environ Microbiol 78:6078-6086
Tyler G (2004) Rare earth elements in soil and plant systems - a review. Plant Soil 267:191-206

Wei Z, Liang X, Pendlowski H, Hillier S, Suntornvongsagul K, Sihanonth P, Gadd GM (2013) Fungal biotransformation of zinc silicate and sulfide mineral ores. Environ Microbiol 15:2173-2186

White C, Gadd GM (1990) Biosorption of radionuclides by fungal biomass. J Chem Technol Biotechnol 49:331-343

Xie J, Lin Y, Li C, Wu D, Kong H (2015) Removal and recovery of phosphate from water by activated aluminum oxide and lanthanum oxide. Powder Technol 269:351-357

Zhan G, Yu J-X, Xu Z-G, Zhou F, Chi R-A (2012) Kinetics of thermal decomposition of lanthanum oxalate hydrate. Trans Nonferr Metal Soc 22:925-934

Zhang L, Wan L, Chang N, Liu J, Duan C, Zhou Q, Li X, Wang X (2011) Removal of phosphate from water by activated carbon fiber loaded with lanthanum oxide. J Hazard Mater 190:848-855

Zhang Y, Zhu W, He H, Zheng A (2014) Synthesis of lanthanum oxalate hierarchical micro-particles and nano-tubes. J Exp Nanosci 9:851859 